\title{
YOUTH'S FAVORITE ACTIVITIES DURING THE COVID-19 PANDEMIC AT SMA X LAMPUNG SELATAN
}

\author{
Fairuz Salsabila \\ Universitas Islam Negeri Sunan Kalijaga Yogyakarta, 20200012016@student.uin-suka.ac.id
}

Nurus Sa'adah

Universitas Islam Negeri Sunan Kalijaga Yogyakarta,nurus.saadab@uin-suka.ac.id

\author{
(c) (1) (b) \\ (C)2020 by the authors. Submitted for possible open access publication under the terms and conditions \\ of the Creative Commons Attribution-ShareAlike 4.0 International License (CC-BY-SA) \\ license (https:/ / creativecommons.org/licenses/by-sa/4.0/) \\ a DOI :http://dx.doi.org/10.30983/ humanisme.v5i2 \\ \begin{tabular}{l|l|l} 
Submission: September 24, 2021 & Revised : December 12, 2021 & Published: December 31, 2021
\end{tabular}
}

\begin{abstract}
COVID-19 is not over yet. This long-lasting pandemic certainly impacts teenagers, including the intensity of the use of gadgets in adolescents to increase and trigger boredom to trigger stress in adolescents. To overcome this, the thing that teenagers do is do their favorite activities. In this study, the author explains teenagers' favorite activities in class XI IPA at SMA X South Lampung during the pandemic concerning the theory of symbolic interaction. This research uses descriptive qualitative with data collection techniques through observation, interviews, and documentation. The study's result shows that the dominant and favorite activity of teenagers during the COVID-19 pandemic is playing with their gadgets by browsing social media such as Instagram, Facebook, youtube, and others. There are other favorite activities, which are physical activities such as volleyball, soccer, and marathons in addiction, as well as activities that contain religious elements such as reading the Qur'an and reading Islamic novels. Thus, teenagers' favorite activities are essential and for teenagers so that they can develop their potential.
\end{abstract}

Keywords: Teenagers, Favorite Activities, Pendemi Period.

\begin{abstract}
Abstrak
COVID-19 belum berakhir. Pandemi yang berlangsung lama ini tentu membawa dampak bagi remaja, di antaranya intensitas penggunaan gawai pada remaja menjadi meningkat dan memicu timbulnya rasa bosan hingga memicu terjadi stress pada remaja. Untuk mengatasi hal tersebut, hal yang dilakukan remaja yakni melakukan kegiatan favoritnya. Dalam penelitian ini penulis menjelaskan kegiatan favorit apakah yang dilakukan remaja kelas XI IPA 5 di SMA X Lampung Selatan pada masa pandemi dalam kaitannya dengan teori interaksi simbolik. Adapun metode dalam penelitian ini yaitu menggunakan deskriptif kualitatif dengan teknik pengumpulan data melalui observasi, wawancara, dan dokumentasi. Berdasarkan hasil penelitian menunjukkan bahwa kegiatan yang dominan dan menjadi favorit remaja pada masa pandemi COVID-19 ini ialah bermain dengan gawainya dengan menelusuri media sosial seperti instagram, facebook, youtube, dan lainnya. Di samping itu masih ada kegiatan favorit lain, yakni kegiatan fisik atau berolahraga seperti olahraga volly, sepak bola dan marathon. serta kegiatan yang mengandung unsur keagamaan seperti membaca Al-Qur'an dan membaca novel Islami. Dengan demikian, kegiatan favorit remaja merupakan hal yang penting dan bagi remaja sehingga mereka mampu mengembangkan potensi dirinya.
\end{abstract}

Kata Kunci : Remaja, Kegiatan Favorit, Masa Pendemi. 


\section{Introduction}

The term adolescence is called adolescence, derived from the Latin word adolescere which means to grow or grow to reach maturity. Adolescence has a broad meaning, including physical, mental, emotional, and social maturity. According to the World Health Organization, early adolescence lasts between the ages of 10-14 years and late adolescence lasts between 1520 years.

Adolescence is a crucial period for changes in physical and psychosocial aspects. Adolescence can also be said to be a time of self-discovery. The discovery of identity means that teenagers can know and determine the purpose of life.

Meanwhile, youth activities tend to form groups to carry out various activities with their peers. Through various activities carried out both inside and outside the home, adolescents can develop selfcompetence, get used to interacting, build good communication, and cooperate with others. ${ }^{1}$

Another research that discusses adolescent activities or activities was carried out by Jasni who stated that religious development was essential to minimize deviant behavior during adolescence. The coaching includes recitation, sharing of knowledge, holding sports and arts activities, holding social activities, and celebrating Islamic holidays. This study is supported by other findings that also state that religious activities in Hindu adolescents affect changing adolescent behavior for the better. ${ }^{2}$ Other research that discusses adolescent activities, namely gathering with playmates or

\footnotetext{
${ }^{1}$ Raisha Helau Wardhani, Euis Sunarti, Istiqlaliyah Muflikhati, "Ancaman, Faktor Profektif, Aktivitas dan Resiliensi Remaja: Analisis Berdasarkan Tipologi Sosio demografi", Jurnal Ilmu Keluarga dan Konsumen, Vol.10, No.1, (2017), 49.

2I Nyoman Temon Astawa, Perubahan Perilaku Remaja Hindu dalam Menjalankan Aktivitas Keagamaan di Kota Denpasar', Guna Widya: Jurnal Pendidikan Hindu, Vol. 5 No.1 (November 2018).
}

more often referred to as "hanging out"3. Then, research related to adolescent physical activity, revealed by Putri, Lestari and Nilawati that the Healthy and Productive Youth Movement is also one of the activities favored by teenagers, besides that it can also prevent negative behavior. ${ }^{4}$ In addition, physical activities, especially volleyball can be a means of reducing online games ${ }^{5}$. In a study on physical activities related to people with autism, it was explained that physical activity is one of the favorite activities that are often done because it can increase their understanding of themselves ${ }^{6}$.

However, the current reality is that the world is still shocked by the spread of the corona virus (Corona Virus Disease), or more familiarly known as Covid-19. The cause of the emergence of this virus is still unknown at first. However, the World Health Organization revealed that this corona virus has continued to be debated since last December 2019, and it was stated that this virus first came from the city of Wuhan, China whose etiology is unknown ${ }^{7}$. Globally, the graph of Covid-19 cases continues to increase. As of April 26, 2021, there have been $146,841,882$ confirmed cases

\footnotetext{
${ }^{3}$ Muhammad Sultan, 'Studi Paradigma Naratif Walter Fisher Pada Aktivitas "Nongkrong" Di Kalangan Remaja Madya', Jurnal AlKhitabah, Vol. 3 No. 1, (Juni 2017).

4 Risma Alviani Putri, Puji Lestari, Ika Nilawati, 'Gerakan Remaja Sehat dan Produktif (GERATIF) sebagai Upaya Preventif Perilaku Beresiko Remaja', Indonesian Journal of Community Empowerment, Vol. 2 No. 1 (Mei 2020).

${ }^{5}$ Jeki Sandra Bujang, Sulastri, Indra Agung Pradita, 'Olahraga Volly Sebagai Sarana Mengurangi Game Online bagi Remaja di desa Jambat Akar Kabupaten Saluma', Jurnal Dharma Pendidikan dan Keolabragaan, Vol. 1 No. 1, (2021).

${ }^{6}$ Clark, M. \& Adams, D. 'The Self-identified Positive Attributes and Favorite activities of children on the autism spectrum.' Elsevier.(2020).

${ }^{7}$ Lee, A. (2020). 'Wuhan Novel Coronavirus (CVID-19): Why Global Control is Challenging?'. Public Health. 179. A1-A2.
} 
of COVID-19, including 3,104,743 deaths, reported to WHO (WHO Coronavirus Dashboard, 2021). In Indonesia itself, the development of COVID-19 cases can be said to be very fast. Exactly in March 2020 President Joko Widodo and his staff announced the first positive case of Covid-19 and until April 26, 2021 it was recorded that $1,647,138$ positive cases of Covid-19 had spread in Indonesia ${ }^{8}$.

A survey conducted by Komnas Perempuan from April to May 2020 in 34 provinces of Indonesia showed that during the Covid-19 pandemic, the burden of household work increased and women carried more burdens. It affects the psychology of parents, especially mothers, which can then become an obstacle for parents in supporting their child's learning process. $^{9}$

In addition, the Covid-19 pandemic has prevented teenagers from optimizing their favorite activities because teenagers are focused on the online learning process. Online learning is learning that is carried out without meeting face to face with an internet-based learning system ${ }^{10}$. Online learning is also a learning model that eliminates distance and time with the help of a digital platform so that it supports the learning process without any physical interaction $^{11}$. Online learning can be

${ }^{8}$ Herlina,https:/ / nasional.kontan.co.id/ news/ update -corona-indonesia-senin264-tambab-5944-kasus-bindarikerumunan. Diakses pada tanggal 26 April 2021.

'Yelly Elanda, 'The Construction of an Ideal Mother Amid the Covid-19 Pandemi : Gender Injustice Experienced by Career Women While Working From Home', Humanisma: Journal of Gender Studies, Vol. 5, No. 1, (Januari 2021), h. 25.

${ }^{10}$ Lestari, P.A.S \&Gunawan. 'The Impact of Covid-19 Pandemic on Learning Implementation of Primary and Secondary School Levels'. Journal ofElementary and Childhood Eduction. Vol. 1 No. 2 (2020). 59.

${ }^{11}$ Riski Saga Putra \& Irwansyah, I. 'Media Komunikasi Digital, Efektif Namun Tidak Efisien, interpreted as an experience in transferring knowledge through various media, such as through video, images, text communication, online communication, and other media that support $^{12}$. This online learning process is implemented during the pandemic in almost all educational institutions both at home and abroad $^{13}$. The online learning process can be the best alternative to replace conventional classroom settings ${ }^{14}$. These various learning innovations are supported by the world's entry into the industrial revolution 4.0 where knowledge cannot be separated from technology ${ }^{15}$.

However, on the other hand, online learning turns out to be many problems because not all parties can implement government policies in carrying out the learning process that uses the assistance of this technology. There are several obstacles that educators and students feel, including the unpreparedness of human resources (educators, students or parents), the absence of an appropriate curriculum, and inadequate infrastructure, such as the limited availability of technological facilities and limitations of the internet network. in some areas ${ }^{16}$.

Studi Meida Richness Theory dalamPembelajaran Jarak Jauh BerbasisTeknologi di Masa Pandemi'. Jurnal Ilmu Sosial dan Ilmu Politik. Vol. 1 No.2. (2020).

${ }^{12}$ Giorgi Basilaia\&David Kavavadze. 'Transition to Online Education in Schools during a SARS-CoV-2 Coronavirus (COVID-19) Pandemic in Georgia'. Journal of Pedagogical Research. Vol. 5, No. 4. (2020).

${ }^{13}$ Karen Goldschmidt. 'The COVID-19 Pandemic: Technology Use to Support the Welbeing of Chlidren'. Journal of Pedriatic Nursing.(2020).

${ }^{14}$ Baber, H.' Modeling the Acceptance of Elearning During the Pandemic of COVID-19- A Study of South korea'. Journal of Management Education. Vol. 19 No.2, (2021).

${ }^{15}$ Banggur, M.D.V, Situmorang, R. \&Rusmono. 'Pengembangan Pembelajaran Berbasis Blended Learning pada Mata Pelajaran Etimologi Multimedia'. Jurnal Teknologi Pendidikan. Vol. 20 No.2. (2018), 5.

${ }^{16}$ Fieka Nurul Arifa, Tantangan Pelaksanaan Kebijakan Belajar Dari Rumah dalam Masa Darurat 
Internet access is one of the main problems in the online learning process ${ }^{17}$. Another obstacle that is also felt due to learning using technology assistance is causing the intensity of the use of gadgets to be higher which can then cause new problems for teenagers.

Another problem that arises as a result of online learning is the emergence of feelings of anxiety, frustration, and boredom which in turn affects the thinking process ${ }^{18}$. Other studies also reveal that mental health disorders will have an impact on a person's academic performance decline ${ }^{19}$. In Indonesia, problems related to mental health caused by online learning are the emphasis on tasks with short durations and too heavy. It was recorded that from March 16 to April 9 2020, the Komisi Perlindungan Anak Indonesia (KPAI) received approximately 213 reports regarding online learning that created unrest and became a new problem in daily life ${ }^{20}$. Tasks that are too heavy and too short of time can trigger boredom, boredom and stress. This stress can arise when

Covid19, Kajian Singkat terbadap Isu Aktual dan Strategis, Vol. 12 No. 7, (April 2020), 15.

${ }^{17}$ Beby Masitho Batubara, 'The Problems of the World of Education in the Middle of the Covid19 Pandemic'. Budapest International Research and Critics Institute-Journal. Vol. 4, No. 1. (2021).

${ }^{18}$ Van Bavel, J.J., Baicker, K., Bogio, P.S., Capraro, V., Cichocka, A., Cikara, M., Crockett, M.J., Crum, A.J., Douglas, K.M., Druckman, J.N. Drury, J. 'Using Social and Behavioral Science to Supprot COVID-19 Pandemic Respons'. Nat.Hum. Behavior.Vol. 4 No. 5,(2020). 460-471.

${ }^{19}$ Rohr, S., Mullier, F., Jung, f., Apfelbacher, C., Seidler, A., Riedel-Heller, S.G. 'Psychosoziale Folgen von Quarantanemabnabmen bei schwerweigenden CoronavirusAusbruchen: ein Rapid Review'. Psychiatr. Vol. 47 No. 4. (2020). Aylie, N.S., Mekonen, M.A., Mekuria, R.M. 'The Psychology Impacts of COVID-19 Pandemic among Univercity Students in Bench-Sheko Zone, South-West Ethiopia: a Community-Based CrossSectional Study'. Psychol. Res. Behavior Managed. 13. (2020). 813-821.

${ }^{20}$ Fieka Nurul Arifa, Tantangan Pelaksanaan Kebijakan Belajar Dari Rumah dalam Masa Darurat Covid19, Kajian Singkat terhadap Isu Aktual dan Strategis, Vol. 12 No. 7, (April 2020), 15. teenagers (students) get many demands with many tasks, but these teenagers have not adapted to new learning models and lack understanding of the learning material. Even though the learning process must continue, because education is one of the crucial things in life. ${ }^{21}$

To reduce the boredom experienced by high school teenagers during this pandemic, they do their favorite activities. Therefore, this study explains what teenagers carry out favorite activities at SMA X South Lampung during the pandemic concerning symbolic interaction theory. The reason for choosing this theory is that the activities carried out by teenagers have their symbols or meanings, including playing social media so that they can form a wide communication network which is interpreted as the ability to interact, and gathering with friends with various characters will form the meaning of solidarity. These activities are also inseparable from the symbolic interactions formed by the teenagers. Meanwhile, the reason for choosing SMA $\mathrm{X}$ as the research location is because the SMA is one of the schools in South Lampung Regency that has advantages in the extracurricular field.

\section{Methods}

This research uses qualitative research methods with the type of field research. The nature of this research is descriptive. Descriptive research is structured to provide a systematic description of scientific information originating from the subject or object of research ${ }^{22}$. The description in this study describes the favorite activities of teenagers during the pandemic.

21 Nurhasanah, 'Women Student Motivation in Learning Arabic Language During the Covid-19 Pandemic',Humanisma : Journal of Gender Studies, Vol. 5, No. 1. (2021). 82.

${ }^{22}$ Anwar Sanusi, Metodologi Penelitian Bisnis, (Jakarta Selatan: Selemba Empat, 2011), 13. 
The subjects of this study were 10 teenagers in class XI IPA 5 at SMA X South Lampung. Based on information from school counselors and homeroom teachers, it was found that the 10 teenagers were in the category of teenagers who were active in non-academic activities and were quite intent on playing gadgets. The activeness and intention are the criteria in this study.

Furthermore, the main focus of the research is to find out what teenagers' favorite activities can be done amid the covid-19 pandemic in class XI IPA 5 teenagers at SMA $\mathrm{X}$ South Lampung. Sources of data used are primary data and secondary data. Primary data was obtained from interviews with several informants, while secondary data was obtained from data collection that supports primary data, namely by searching for research literature related to the focus of this research. Furthermore, data collection techniques were obtained from interviews, observations, and documentation to obtain accurate data or information.

The research was conducted through three stages. The first stage is to determine the appropriate questions to the research topic. Second, determine the right subject to be the target of research. Third, conducting interviews on research subjects determined and interviews with families and homeroom teachers. Fourth, look for data or information related to informants. The last stage is analyzing the data. Data analysis in this study refers to the Miles and Huberman model analysis, which consists of several series, namely data reduction, data presentation, and drawing conclusions or verification. As for the application of a series of research data analysis, namely, data reduction, the researcher grouping teenagers who have similar favorite activities, presents the reduced data in a narrative form, and draws conclusions or verification.

\section{Discussion}

\section{Adolescents and their Activities during the Pandemic}

Based on the results of data collection obtained from 10 teenagers in class XI IPA 5 at SMA X South Lampung who are included in the criteria for this study, it shows that teenagers' favorite activities during the pandemic are very dominant using gadgets, such as watching YouTube and playing social media (such as opening applications). TikTok, Instagram, Whatsapp, Facebook and more). In line with the research results, which states that various activities of today's youth have been dominated by technological sophistication in the form of gadgets. The sophistication of the features provided can attract the curiosity of teenagers to explore further about the favorite activities or what the teenager likes ${ }^{23}$.

It is following the recognition of the teenagers with the initials TN, DA, AF, TO, LA, IM, ZN, AA, NA, and SY stating that their favorite activity during the pandemic is leading to technological sophistication such as using various devices interest. These interests include doing school assignments from each subject that is very dependent on internet technology and seeking entertainment in cyberspace to minimize boredom. This is what causes teenagers to become dependent on their gadgets. This finding is supported by previous studies which state that the factors that influence the dominance of gadget use activities in adolescents today are motivated by several things, such as boredom ${ }^{24}$, dislike of online

${ }^{23}$ Danan Saputra, Muh.Arsyad, Ambo Upe, "Potret Sosial Remaja Masa Kini (Study pada Remaja Pengguna Smartphone di Kelurahan Kambu Kambu Kota Kediri",Jurnal Neo Societal, Vol.3, No.3, (Oktober 2018), 550.

${ }^{24}$ Pang, H. How compulsive WeChat use and information overload affect social media fatigue and well-being during the COVID-19 pandemic? A 
learning, stress during the COVID-19 pandemic $^{25}$, there is a crisis of productive activity $^{26}$, and the prohibition of social relations with many people so that the gadget is the only right solution because they cannot do activities with their friends by meeting physically.

It is in line with the opinion of Peg Streep, a digital observer and teenager, who explained that there are four reasons why teenagers are very interested in using social media. First, to get attention. The second is to ask for opinions or get recognition for fame. Third, cultivate a self-image built based on sincerity or just a trick. Furthermore, the fourth is an addiction ${ }^{27}$. In addition, teenagers consider social media as an intermediary in finding their identity.

Furthermore, another favorite routine activity for teenagers is gathering with their peers. It is following one of the tasks of adolescent development proposed by Havigurst, namely that adolescents can achieve new and more mature relationships with peers, both male and female, and can achieve their social roles. ${ }^{28}$

In line with that, Wardani, Sunarti, and Muflikhati explained that youth activities are teenagers' tendencies to form groups by

stressor-strain-outcome perspective. Telematics and Informatics, Vol 64. (2021).

25 Daniels, A. Wellan, S.A., \& Walter, H. Learning it the hard way - how enjoying life and positive appraisal buffer the negative effects of stressors on mental health in the COVID-19 pandemic. Journal of Affective Disorders Reports Vol 6, (2021). 1-10.

26 Mastronardi, L., Cavallo, A., \& Romagnoli, L. How did Italian diversified farms tackle Covid-19 pandemic first wave challenges? (2021).

${ }^{27}$ Pamela Felita, et.al, "Pemakaian Media Sosial dan Sel Concept pada Remaja", Jurnal Ilimiah Psikologi MANASA, Vol. 5, No.1, (2016), 32.

${ }^{28}{ }_{2}$ Hurlock B. Elizabeth, Psikologi Perkembangan Sebuah Pendekatan Sepanjang Rentang Kehidupan Edisi Kelima, (Erlangga : 1980), 10. doing various activities with their peers. This opinion is in line with the findings in this study, such as the expressions of AF and LA as follows,

"After doing my schoolwork as an obligation, then I do my favorite activities, which are playing with friends and taking an afternoon walk 29 ." (excerpt from interview with AF). "My favorite activities during this pandemic are watching TikTok, watching YouTube, and playing with my friends ${ }^{30}$." (interview excerpt with LA).

This statement explains that teenagers are inseparable from their tendency to form a group. With the existence of social restrictions, it turns out that it is not an obstacle for teenagers to play with their peers.

The next favorite activity for teenagers is related to physical activity. Physical activity such as exercising is also an activity that teenagers often do. Physical activity is a body movement produced by skeletal muscles that require energy expenditure. Physical activity is significant to maintaining physical and mental health and maintaining a healthy life quality. Especially during the current pandemic, physical activity is essential to maintain self-resistance from various diseases because low physical activity can trigger the development of obesity in adolescents $^{31}$.

The explanation above is in line with the statements of SY, TO, and ZN who said that their favorite activity during the pandemic is exercising.

\footnotetext{
${ }^{29} \mathrm{AF}$,(Siswa SMA X Lampung Selatan), Interview, \{Kamis, 29 April 2021\}

${ }^{30}$ LA,(Siswa SMA X Lampung Selatan), Interview, \{ Kamis, 29 April 2021\}

${ }^{31}$ Yudha Wahyu Putra, Amalia Solichathi Rizqi, "Indekx Massa Tubuh (IMT) Mempengaruhi Aktivitas Remaja Putri SMP Negeri 1 Sumberwangi”, Jurnal Aiska-University, Vol.16. No.1, (2018), 107.
} 
"My favorite activity is playing volleyball with friends ${ }^{32}$." (excerpt from interview with $\mathrm{ZN}$ ).

"One of my favorite activities is practicing football. I practice soccer to relieve boredom due to this covid-19 pandemic ${ }^{33}$." (excerpt from interview with TO).

"Besides watching YouTube and opening the TikTok application, I also have a favorite activity of running/marathon. Because I feel that if my body is not cultivated, it will be easy for me to get sick ${ }^{34}$." (excerpt from interview with SY).

It is in line with research conducted by Ali Budiman which states that adolescents tend to prefer playing soccer, basketball, and volleyball, compared to traditional sports such as stilts, tug of war, and pencak silat. This comparison is seen in adolescents who are in rural and urban areas. Traditional sports activities are still carried out for teenagers who live in rural areas. However, these activities are rarely carried out for teenagers who live in urban areas due to the lack of facilities. Another influence of modernization and globalization is that teenagers prefer to play online games, social media or play gadgets to fill their spare time $e^{35}$.

From the explanations of the three teenagers above (ZN.TO, SY) it is known that volleyball, soccer, and marathon are their favorite sports because they have been

\footnotetext{
${ }^{32} \mathrm{ZN}$,(Siswa SMA X Lampung Selatan), Interview, \{ Kamis, 29 April 2021\}

${ }^{33}$ TO,(Siswa SMA X Lampung Selatan), Interview, \{ Kamis, 29 April 2021\}

${ }^{34}$ SY,(Siswa SMA X Lampung Selatan), Interview, \{ Kamis, 29 April 2021\}

${ }^{35} \mathrm{Ali}$ Budiman, "Aktivitas Olahraga Tradisional pada Kalangan Remaja di Masa Pandemi Covid-19”, Journal of Physical and Outdoor Education, Vol. 3, No.1, (1 April 2021).
}

involved in these sports for a long time, they feel comfortable with these sports, even their motivation to enter SMA X South Lampung is because interested in the flagship sports extracurricular program.

Some of the other youth's favorite activities are drawing, reading Islamic novels and blogs related to learning, making literacy videos, and reading the Qur'an. This is in accordance with what they stated:

"Reading the Qur'an is one of my favorite activities besides playing games and watching videos on YouTube" ${ }^{136}$." (excerpt from interview with IM).

"The activities that I often do during the pandemic are exploring the world of YouTube, making literacy videos, reading Islamic novels, and opening blogs related to learning ${ }^{37}$." (excerpt from interview with AA).

"Watching tiktok videos, youtube and opening instagram are my favorite activities. But another favorite activity is reading the Qur'an ${ }^{38 . " ~(e x c e r p t ~ f r o m ~}$ interview with NA).

Reading the Qur'an and always adding to Islamic insight is one of the favorite activities for some teenagers because they believe that it can be self-control especially when teenagers are feeling pressured by the various tasks at hand.

From the results of Rokhmawan, et.al's research, which examined the positive activities of teenagers during the pandemic, it was explained that the positive activities of teenagers were directed at developing Islamic arts and cultural activities such as Recitation

\footnotetext{
${ }^{36}$ IM,(Siswa SMA X Lampung Selatan), Interview, \{ Kamis, 29 April 2021$\}$

${ }^{37}$ AA,(Siswa SMA X Lampung Selatan), Interview, \{ Kamis, 29 April 2021$\}$

${ }^{38} \mathrm{NA}$,(Siswa SMA X Lampung Selatan), Interview, \{ Kamis, 29 April 2021\}
} 
of the Qur'an, Art of Hadrah Al-Banjari and Kultum. The development of Islamic arts and cultural activities is expected to help teenagers to be able to carry out positive activities during the pandemic ${ }^{39}$.

The Relation of Symbolic Interaction

Theory to Adolescents' Favorite
Activities during the COVID-19
Pandemic

Symbolic interaction is a branch of sociology from an interactionist point of view. Symbolic interaction, according to this view is one of the views in communication science. This view assumes that every individual has the essence of culture, interacts in the social community, and produces the meaning of a mutually agreed upon thought ${ }^{40}$.

Scott Plunkett defines symbolic interaction as the way we learn to interpret and give meaning or meaning to the world through interactions with other people $e^{41}$.

Thus, it can be said that symbolic interaction is a way of introspection to find out something or the meaning behind one's point of view by studying social action. Thus, it can be seen that humans act not only because of the stimulus but based on the meaning given to the action.

The essence of symbolic interaction theory is an approach to the individual that emphasizes the relationship of symbols and interactions. The fundamental character of this theory is the relationship that occurs

\footnotetext{
${ }^{39}$ Tristan Rokhmawan, et. al. "Pengembangan Kegiatan Seni dan Budaya Islami Sebagai Bentuk Kegiatan Positif Remaja Pada Masa Pandemi di DesaSumber Dawe Sari Kecamatan Greti Kabupaten Pasuruan", Jurnal Pengabdian Kepada Masyarakat, Vol.1 No.2 (2020).

${ }^{40}$ Nina Siti Salmaniah Siregar, "Kajian Tentang Interaksionisme Simbolik", Jurnal Ilmu Sosial, Vol. 1, No. 2, (2012), 103.

${ }^{41}$ Aidil Haris, Asrinda Amalia, "Makna dan Simboldalam Proses Interaksi Sosial (Sebuah Tinjauan Komunikasi)", Jurnal Risalah, Vol.29, No. 1, (Juni 2018), 18.
}

naturally between humans in society and society with individuals.

Symbolic interaction has five basic concepts, namely self-concept, action concept, object concept, social interaction concept, and joint action concept:

1. Self-concept, is a form of a person's awareness of himself and not merely moving because of a stimulus from outside or within himself.

2. The concept of action illustrates that humans do actions not solely because of natural conditions that occur but because of the interpretation formed through intrapersonal interaction.

3. The object concept, which views humans as being among material objects or something abstract, such as the concept of freedom or philosophy. The essence of these objects is determined by the interest and meaning.

4. The concept of social interaction, which means understanding and positioning oneself as another person in order to create a meaningful relationship through communication.

5. Joint action, namely the alignment of the meaning, thoughts, and attitudes of an individual with other individuals ${ }^{42}$.

The relationship between the theory of symbolic interaction with the favorite activities of teenagers are:

First, Self-Concept. Self-concept is a process of individual social interaction with other people. Regarding the favorite activities of teenagers during the pandemic, it can be seen in the subjects with the initials $\mathrm{AF}$ and LA who have a tendency to form selfconcepts through interactions with their peers.

Second, the concept of action. This concept describes an act carried out because

\footnotetext{
${ }^{42}$ Ahmadi, “Interaksi Simbolik : Suatu pengantar”, Jurnal Komunikasi, Vol. 9, No. 2, (2008), 303.
} 
of an interpretation formed through the process of intrapersonal interaction. This is related to the youth's favorite activity in the form of sports, as expressed by TO, SD and ZN. This activity shows the concept of action that is formed through intrapersonal interaction between the individual himself because he realizes that sport has many positive impacts. This is in line with the activities favored by the Prophet Muhammad, namely exercising to maintain body fitness. It is also explained in the hadith that the Prophet SAW said:

"The strong believer is better and more beloved to Allah than the weak believer, and in both there is goodness." (H.R. Muslim)

Third, Object Concept. The concept of object views that humans are among many objects such as something abstract and the essence of this object is determined by the interest and meaning given to the object. Regarding youth's favorite activities, reading the Qur'an and reading Islamic novels can become object concepts because something related to Allah is an abstract thing, as well as reading the Qur'an and reading Islamic novels is one of the activities that can be interpreted as an intermediary for the individual's closeness to His Creator. The benefits of reading the Qur'an are that it can reconcile hearts, increase emotional and spiritual intelligence, get guaranteed intercession in the hereafter, always get the grace of Allah SWT.

Fourth, the concept of social interaction. The concept of social interaction means understanding and positioning oneself as another person in order to create meaningful relationships. In relation to teenagers' favorite activities during the pandemic, the social interactions they build dominate interactions through social media.
The interaction through social media is in the form of chatting via WhatsApp, seeing other people's activities via Instagram, YouTube and TikTok. This was confirmed by AF, TO, LA, IM, ZN, AA, NA, TN, SY and DA, who stated that sailing in the world of social media was one of their favorite activities. The concept of social interaction is related to the concept taught in Islam, namely Hablumminannas, namely the concept where individuals can maintain good relations with other individuals. As the words of the Prophet Muhammad in the hadith which reads:

"A Muslim is another Muslim's brother. Therefore, do not oppress and belittle him and do not hurt him." (H.R. Ahmad, Bukhori dan Muslim).

Fifth, Joint Action. Joint action is the alignment of the meaning, thoughts, and attitudes of an individual with other individuals. In the basic concept of this joint action, there is no connection with the favorite activities of teenagers because of the ongoing Covid-19 pandemic, activities related to groups are rarely carried out.

\section{Conclusion}

The COVID-19 pandemic, which calls for implementing an online learning system, has brought various impacts for teenagers. Some of the impacts are the increasing use of gadgets in adolescents due to the tasks that must be completed. In addition, prolonged COVID-19 also causes boredom and even triggers stress in teenagers.

The COVID-19 pandemic, which calls for implementing an online learning system, has brought various impacts for teenagers. Some of the impacts are the increasing use of gadgets in adolescents due to the tasks that must be completed. In addition, prolonged COVID-19 also causes boredom and even triggers stress in teenagers. 
To overcome this, the way teenagers do is to do their favorite activities. The discussion of this teenager's favorite activity is related to the theory of symbolic interaction by looking at the symbols formed by teenagers and the interactions that are built with each other. Based on the results of this study, it was found that the favorite activity of teenagers to do is play with their gadgets by browsing social media such as Instagram, Facebook, YouTube, and others. In addition, there are other favorite activities, namely physical activities or sports such as volleyball, soccer and marathons. As well as activities that contain religious elements such as reading the Qur'an and reading Islamic novels.

Therefore, the favorite activities carried out by teenagers are essential and valuable for teenagers so that they can develop their potential and minimize negative behavior.

\section{References}

\section{Journal}

Ahmadi, D. Interaksi Simbolik : Suatu pengantar. Jurnal Komunikasi. Vol. 9, No. 2. 2008. h, 303.

Arifa, F,N. Tantangan Pelaksanaan Kebijakan Belajar Dari Rumah dalam Masa Darurat Covid19. Kajian Singkat terhadap Isu Aktual dan Strategis. Vol. 12, No. 7. 2020. h, 15.

Astawa, I.N.T. 'Perubahan Perilaku Remaja Hindu dalam Menjalankan Aktivitas Keagamaan di Kota Denpasar', Guna Widya: Jurnal Pendidikan Hindu, Vol. 5 No.1 2018.

Aylie, N.S., Mekonen, M.A., Mekuria, R.M. The Psychology Impacts of COVID-19 Pandemic among Univercity Students in Bench-Sheko Zone, South-West Ethiopia: a Community-Based CrossSectional Study. Psychol. Res.
BehaviorManaged. 13. 2020. 813821.

Baber, H. Modeling the Acceptance of E-learning During the Pandemic of COVID-19-A Study of South korea. Journal of Management Education. Vol. 19, No. 2. 2021.

Banggur, M.D.V, Situmorang, R. \& Rusmono. Pengembangan Pembelajaran Berbasis Blended Learning pada Mata Pelajaran Etimologi Multimedia. Jurnal Teknologi Pendidikan. Vol. 20, No. 2. 2018.

Basilaia, G. \& Kavavadze, D. Transition to Online Education in Schools during a SARS-CoV-2 Coronavirus (COVID19) Pandemic in Georgia. Journal of Pedagogical Research. Vol. 5, No. 4. 2020 .

Batubara, B.M. The Problems of the World of Education in the Middle of the Covid-19 Pandemic. Budapest International Research and Critics InstituteJournal. Vol. 4, No. 1. 2021.

Budiman, A. Aktivitas Olahraga Tradisional pada Kalangan Remaja di Masa Pandemi Covid-19. Journal of Physical and Outdoor Education. Vol. 3, No. 1. 2021.

Budiyati, G,A. \& Eka, O. Stres dan Resiliensi Remaja Di Masa Pandemi Covid-19. Jurnal Kesehatan. Vol. 1, No. 2. 2020. h, 13.

Bujang, J.S. Sulastri. \& Pradita, I.A. 'Olahraga Volly Sebagai Sarana Mengurangi Game Online bagi Remaja di desa Jambat Akar Kabupaten Saluma'. Jurnal Dharma Pendidikan dan Keolahragaan, Vol. 1 No. 1. 2021.

Chaidirman, Indriastuti, D., \& Narmi. Fenomena Kecanduan Penggunaan Gawai (Gedget) pada Kalangan Remaja Suku Bajo. Journal of Holistic Nursing and Health Science. Vol. 2, No. 2. 2019. 
Clark, M. \& Adams, D. The Self-identified Positive Attributes and Favorite activities of children on the autism spectrum. Elsevier. 2020.

Elanda, Y. The Construction of an Ideal Mother Amid the Covid-19 Pandemi : Gender Injustice Experienced by Career Women While Working From Home. Humanisma: Journal of Gender Studies. Vol. 5, No. 1. 2021.

Felita, P. dkk. Pemakaian Media Sosial dan Self Concept pada Remaja. Jurnal Ilimiah Psikologi MANASA. Vol. 5, No. 1. 2016. h, 32.

Goldschmidt. The COVID-19 Pandemic: Technology Use to Support the Welbeing of Chlidren. Journal of Pedriatic Nursing. 2020.

Haris, A. Asrinda, A. Makna dan Simbol dalam Proses Interaksi Sosial (Sebuah Tinjauan Komunikasi). Jurnal Risalah. Vol. 29, No. 1. 2018. h, 18.

Jasni. 'Partisipasi Remaja Putri terhadap Aktivitas Nasyiatul Aisyiyah di Sunga Pinang Kecamatan Hulu Kuantan'. Jurnal Pendidikan Sosial, Sains, dan Humaniora. Vol. 4 No. 3. 2018.

Lee, A. Wuban Novel Coronavirus (COVID19): Why Global Control is Challenging?. Public Health. 179. A1A2. 2020.

Lestari, P.A.S \& Gunawan. The Impact of Covid-19 Pandemic on Learning Implementation of Primary and Secondary School Levels. Journal of Elementary and Childhood Eduction. Vol. 1, No. 2. 2020.

Makarova, E. A. Aggressive Behavior in Online Games and Cybervictimization of Teenagers and Adolescents. International Electronic Journal of Elementary Education. Vol. 12, No. 2. 2019.

Nurhasanah. Women Student Motivation in Learning Arabic Language During the Covid-19 Pandemic. Humanisma : Journal of Gender Studies. Vol. 5, No. 1. 2021.
Putra, R.S \& Irwansyah, I. Media Komunikasi Digital, Efektif Namun Tidak Efisien, Studi Meida Richness Theory dalam Pembelajaran Jarak Jaub Berbasis Teknologi di Masa Pandemi. Jurnal Ilmu Sosial dan Ilmu Politik. Vol. 1, No. 2. 2020.

Putra, Y,W. \& Amalia, S,R. Indekx Massa Tubub (IMT) Mempengarubi Aktivitas Remaja Putri SMP Negeri 1 Sumberwangi. Jurnal AiskaUniversity. Vol. 16, No. 1. 2018. 107.

Putri, R.A. Lestari, P. Nilawati, I. 'Gerakan Remaja Sebat dan Produktif (GERATIF) sebagai Upaya Preventif Perilaku Beresiko Remaja', Indonesian Journal of Community Empowerment, Vol. 2 No. 1. 2020.

Rokhmawan, T. Dkk. Pengembangan Kegiatan Seni dan Budaya Islami Sebagai Bentuk Kegiatan Positif Remaja Pada Masa Pandemi diDesa Sumber Dawe Sari Kecamatan Greti Kabupaten Pasuruan. Jurnal Pengabdian Kepada Masyarakat. Vol. 1, No. 2. 2020.

Rohr, S., Mullier, F., Jung, f., Apfelbacher, C., Seidler, A., Riedel-Heller, S.G. Psychosoziale Folgen von Quarantanemabnabmen bei schwerweigenden CoronavirusAusbruchen: ein Rapid Review. Psychiatr. Vol. 47, No.4. 2020.

S. Royant Parola, V. Londe, S. Trehout \& S. Harley. (2018). 'The Use of Social Media Modifies Teenagers' SleepRelated Behavior'. Elsevier. 44(1).

Saputra, D. Muh, A. \& Ambo, U. Potret Sosial Remaja Masa Kini (Study pada Remaja Pengguna Smartphone di Kelurahan Kambu Kambu Kota Kediri). Jurnal Neo Societal. Vol. 3, No. 3. 2018. h, 550 .

Siregar, N, S,S. Kajian Tentang Interaksionisme Simbolik. Jurnal Ilmu Sosial. Vol. 1, No. 2. 2016. h, 103. 
Sultan,M. 'Studi Paradigma Naratif Walter Fisher Pada Aktivitas "Nongkrong" Di Kalangan Remaja Madya'. Jurnal Al-Khitabah. Vol. 3 No. 1. 2017.

Van Bavel, J.J., Baicker, K., Bogio, P.S., Capraro, V., Cichocka, A., Cikara, M., Crockett, M.J., Crum, A.J., Douglas, K.M., Druckman, J.N. Drury, J. Using Social and Behavioral Science to Supprot COVID-19 Pandemic Respons. Nat.Hum. Behavior. Vol. 4, No. 5. 2020. 460471.

Wardhani, R,A. Euis, S. \& Istiqlaliyah, M. Ancaman, Faktor Profektif, Aktivitas dan Resiliensi Remaja : Analisis Berdasarkan Tipologi Sosiodemografi. Jurnal Ilmu Keluarga dan Konsumen. Vol. 10, No. 1. 2017. 49.

Yonandi, R. \& Mochamad, N. Kecanduang Game Online (Profil Pecandu, Faktor Penyebab dan Penanganannya. Jurnal BK UNES. Vol. 11, No. 5. 2020. 766.

\section{Books}

Ali, M. \& Mohammad,A. (2014). Psikologi Remaja: Perkembangan Peserta Didik. Jakarta: PT. Bumi Aksara.

Elizabeth, Hurlock B. (1980). Psikologi Perkembangan Sebuab Pendekatan Sepanjang Rentang Kebidupan Edisi Kelima. Erlangga.

Sanusi, A. (2011). Metodologi Penelitian Bisnis. Jakarta Selatan: Selemba Empat.

\section{Article}

Herlina,https://nasional.kontan.co.id/news/ update-corona-indonesia-senin264tambah-5944-kasus-hindarikerumunan. Diakses pada tanggal 26 April 2021.

WH0,https://www.who.int/emergencies/di sease/novel-coronavirus2019. WHOCoronavirus(covid-
19)Dashboard. Diakses pada tanggal 22 April 2021.

\section{Interview}

TN, (Siswa SMA X Lampung Selatan), Wawancara, \{ Kamis, 29 April 2021\}

DA, (Siswa SMA X Lampung Selatan), Wawancara, \{ Kamis, 29 April 2021\}

AF, (Siswa SMA X Lampung Selatan), Wawancara, \{ Kamis, 29 April 2021$\}$

LA, (Siswa SMA X Lampung Selatan), Wawancara, \{ Kamis, 29 April 2021$\}$

SY, (Siswa SMA X Lampung Selatan), Wawancara, \{ Kamis, 29 April 2021\}

TO, (Siswa SMA X Lampung Selatan), Wawancara, \{ Kamis, 29 April 2021$\}$

ZN, (Siswa SMA X Lampung Selatan), Wawancara, \{ Kamis, 29 April 2021\}

IM, (Siswa SMA X Lampung Selatan), Wawancara, \{ Kamis, 29 April 2021\}

AA, (Siswa SMA X Lampung Selatan), Wawancara, \{ Kamis, 29 April 2021\}

NA, (Siswa SMA X Lampung Selatan), Wawancara, \{ Kamis, 29 April 2021\} 